\title{
PEMBERDAYAAN MASYARAKAT DI DESA BLIMBING DALAM PEMBUATAN DAN PENGAPLIKASIAN ANTI NYAMUK CAIR EKSTRAK DAUN KEMANGI
}

\author{
https://doi.org/10.33024/jkpm.v4i6.3754
}

\author{
Choirul Huda ${ }^{1}$, Amalia Eka Putri²
}

1,2STIKes Karya Putra Bangsa Tulungagung

Disubmit: 26 Januari 2021 Diterima: 08 Juni 2021 Diterbitkan: 01 Desember 2021

Email Korespondensi : Hudacoy85@gmail.com

\begin{abstract}
ABSTRAK
Nyamuk Aedes aegypti merupakan vektor penyakit Demam Berdarah Dengue (DBD) yang menjadi penyakit endemik di negara-negara tropis salah satunya Indonesia. Demam berdarah dengue adalah penyakit infeksi yang disebabkan oleh virus dengue dan ditularkan ke manusia dengan gigitan nyamuk Aedes aegypty. Menurut data WHO penyakit demam berdarah sangat berpotensi pada daerah beriklim tropis seperti asia tenggara, dan menurut data kementrian Kesehatan ditemukan 100sampai 500 kasus tiap harinya. Adapun tujuan kegiatan pelatihan singkat ini adalah meningkatkan pengetahuan masyarakat tentang bahaya anti nyamuk berbahan kimia dan peningkatan pengetahuan dan kemampuan masyarakat tentang pembuatan antinyamuk cair berbahan herbal daun kemangi yang aman bagi masyarakat. Adapun kegiatan adalah pelatihan singkat pembuatan antinyamuk cair berbahan dasar kemangi dan pengaplikasiannya. Terdapat peningkatan pengetahuan dan kemampuan masyarakat tentang antinyamuk berbahan herbal daun kemangi.
\end{abstract}

Kata kunci : DBD, anti nyamuk cair, bahan obat tradisional, Kemangi leaf

\begin{abstract}
Aedes aegypti mosquito is a vector of Dengue Fever (DBD) disease that becomes endemic disease in tropical countries such as Indonesia. Dengue fever is an infectious disease caused by dengue virus and transmitted to humans with the bite of the Aedes aegypty mosquito. According to WHO data dengue fever disease is very potential in tropical climates such as southeast Asia, and according to data from the Ministry of Health found 100 to 500 cases every day. The purpose of this short training activity is to increase public knowledge about the dangers of chemical-based mosquito repellent and increase the knowledge and ability of the community about the manufacture of liquid antinyamuk made from kemangi leaf herbs that are safe for the community. The activity is a short training of making liquid antinyamuk made from basil and its application. There is an increase in people's knowledge and ability about antinyamuk made from kemangi leaf herbs.
\end{abstract}

Keywords: DBD, liquid mosquito repellent, traditional medicine materials, Kemangi leaf 


\section{PENDAHULUAN}

Penyakit Demam Berdarah Dengue (DBD) atau Hemrrhagic Fever (DHF) ialah penyakit yang disebabkan virus dengue yang ditularkan melalui gigitan nyamuk Aedes aegyti dan Aedes albbopictus. Per 30 November 2020, terdapat 51 penambahan kasus DBD dan 1 tambahan laporan kematian akibat penyakit demam berdarah dengue. Selain itu, sebanyak 73,35 persen atau 377 kabupaten/kota telah mencapai Incident Rate kurang dari 49 per 100 ribu penduduk.

Kemenkes melaporkan terdapat lima kabupaten/kota dengan kasus DBD tertinggi. Mereka adalah Buleleng (3.313), Badung (2.547), Kota Bandung (2.363), Sikka (1.786), dan Gianyar (1.717). (KepMenkes.Datin.2019)

Masyarakat cenderung menggunakan antinyamuk bakar pasaran yang murah dan cepat bekerja namun mengandung bahan kimia yang kurang aman jika terhirup terlalu sering karena merupakan insektisida buatan (Cahyana dan Andri, 2011), sehingga haruslah dicari alternatif bahan alami untuk meminimalisir efek toksik yang ada pada antinyamuk bakar di pasaran, tumbuhan yang dapat digunakan sebagai bahan alami, salah satunya adalah daun kemangi (Ocimum basilicum Linn). Daun kemangi memiliki aroma wangi yang khas, rasanya agak manis dan dingin. Aroma khasnya berasal dari daunnya. Tanaman ini dapat tumbuh baik di daerah tropis dan tingginya dapat mencapai $1.5 \mathrm{~m}$, daun bewarna hijau dan bunganya tersusun dalam tandan tegak. Kemangi hidup liar di tempat kering yang mendapat sinar matahari (Wijayani, 2014).

Perlunya sebuah inovasi terbaru dalam pembuatan insektisida alami, yaitu daun kemangi (Ocimum basilicum Linn) yang telah menunjukkan aktivitas cukup ampuh sebagai bahan insektisida alami, namun penelitian dengan menggunakan daun kemangi yang berasal dari Tulungagung dalam sediaan antinyamuk cair belum pernah dilakukan, maka saya tertarik untuk melakukan pengembangan mengenai efektivitas ekstrak daun kemangi (Ocimum basilicum Linn) sebagai insektisida terhadap Aedes aegypti dalam sediaan anti nyamuk cair

\section{MASALAH}

Alasan kami memeilih tempat kegiatan di Desa Blimbing rejotangan karena des aini lumayan padat penduduk dan berdasarkan survey, masyarakat belum mengetahui manfaat daun kemangi sebagai anti nyamuk bakar dan bahaya yang di timbulkan tentang antinyamuk bakar berbahan bakar kimia.

Secara umum, solusi yang ditawarkan berupa peningkatan pengetahuan ibu rumah tangga terkait pemanfaatan daun kemangi sebagai antinyamuk cair untuk mengurangi penggunaan antinyamuk yang berbahan dasar zat kimia yang dapat merugikan bagi kesehatan masyarakat. 


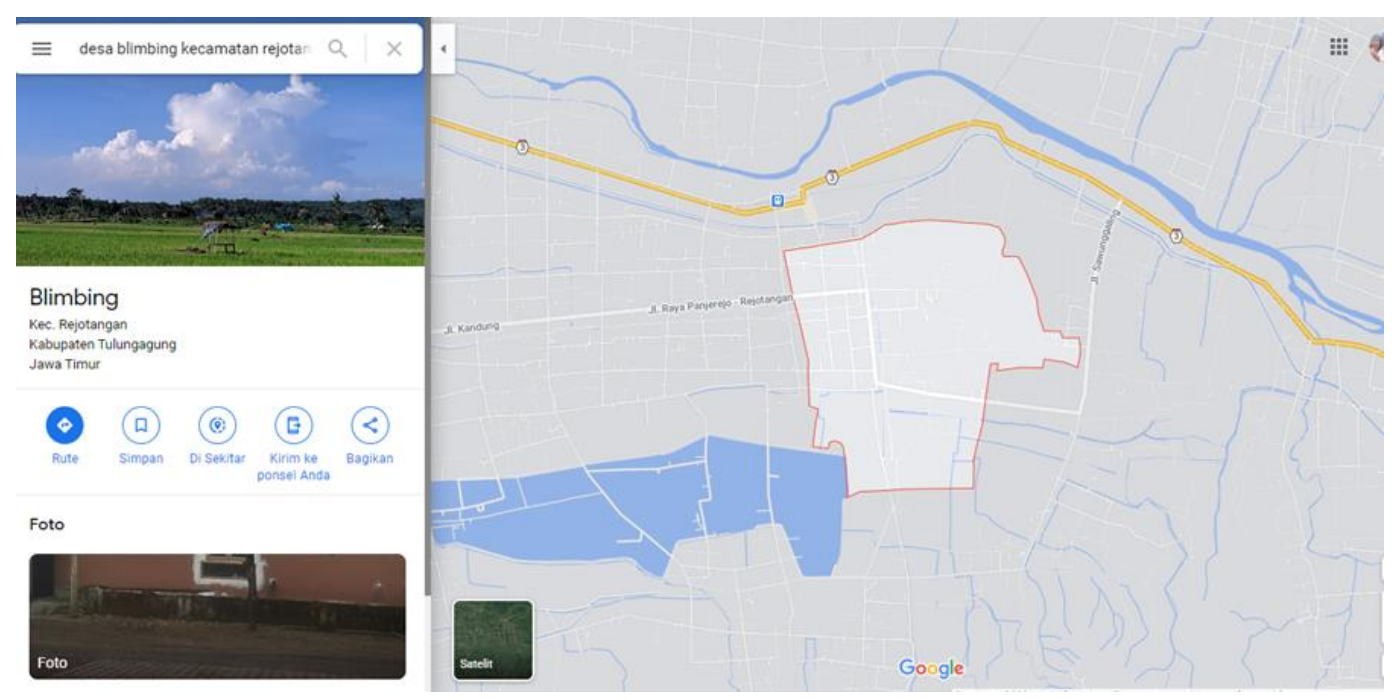

\section{METODE}

\section{a. Tujuan Persiapan}

Memberikan pengetahuan tentang penyakit DBD beserta cara penanganan dan pengobatanya juga pembuatan anti nyamuk alami yang ramah lingkungan di desa Blimbing kecamatan rejotangan Tulungagung.

b. Tahap pelaksanaan

Metode yang digunakan dengan metode ceramah dan tanya jawab. Disamping itu, juga akan diberikan beberapa materi DBD serta praktek pembuatan dan pengaplikasian anti nyamuk cair. Diharapakan setelah adanya kegiatan ini masyarakat dapat membuat anti nyamuk alami sendri yang ramah lingkungan dan aman bagi kesehatan

c. Evaluasi

a. Struktur

Peserta hadir sebanyak 25 orang ibu-ibu pengajian rutinan. Setting tempat sudah sesuai dengan rencana yang dibuat dan perlengkapan yang dilakukan untuk penyuluhan sudah tersedia dan sudah digunakan sebagaimana mestinya. Penggunaan bahasa yang digunakan sudah komunikatif dalam penyampaiannya, Ibu-ibu kumpulan pengajian dapat memahami materi yang sudah disampaikan tim pengabdian masyarakat dan dapat memfasilitasi audiensi selama berjalannya pelatihan dan diskusi.

b. Proses

Pelaksanaan kegiatan sore hari pukul $15.00 \mathrm{~s} / \mathrm{d} 16.30$ WITA. Sesuai dengan jadwal yang telah direncanakan.

\section{HASIL DAN PEMBAHASAN}

Pada pelaksanaan pengabdian kepada masyarakat ini di laksanakan pada sore hari di salah satu rumah warga mayarakat di Dusun Ngremang Desa Belimbing Kecamatan Rejotangan. Pelaksanaan penyuluhan ini di tujukan kepada ibu rumah tangga disana. Media dan alat yang digunakan adalah leafleat serta beberapa tanaman bahan dan produk antinyamuk cair ekstrak daun kemangi, meliputi kemangi, minyak zaitun dan sereh yang dibagikan ke masyarakat desa blimbing. Metode yang digunakan adalah ceramah dan tanya jawab mengenai tanaman obat cara pembuatan antinyamuk cair dan bahaya DBD. Kegiatan ini secara garis 
besar dapat dikatakan baik dan lancar. Peserta adalah kelompok yasinan dan warga atau ibu rumah tangga setempat dapat menghadiri kegiatan ini. Selain itu ada peningkatan pengetahuan sebelum dan sesudah ada kegiatan ini dari peserta tentang pemanfaatan tanaman kemangi sebagai antinyamuk cair sebagai pengganti atau Langkah alternatif yang diambil agar tidak memakai antinyamuk berbahan dasar pertisida yang tidak begitu aman bagi Kesehatan, khususnya pada anak kecil jika dipakai secara terus menerus.

Penyampaian materi dengan metode ceramah dan tanya jawab serta pembagian fotocopy tata cara pembuatan antinyamuk cair berbahan dasar kemangi.evaluasi dilakukan dengan menanyai beberapa peserta tentang tata cara pembuatan antinyamukcair berbahan dasar ekstrak kemangi dan tanya jawab. Pemberdayaan ibu rumah tangga di dusun Ngremang Desa Belimbing Kecamatan Rejotangan dalam pembuatan antinyamukcair dari ekstrak daun kemangi diharapkan dapat terwujud dengan baik melalui pemberian beberapa contoh produk yang sudah jadi.

Berikut gambar pelaksanaan kegiatannya:
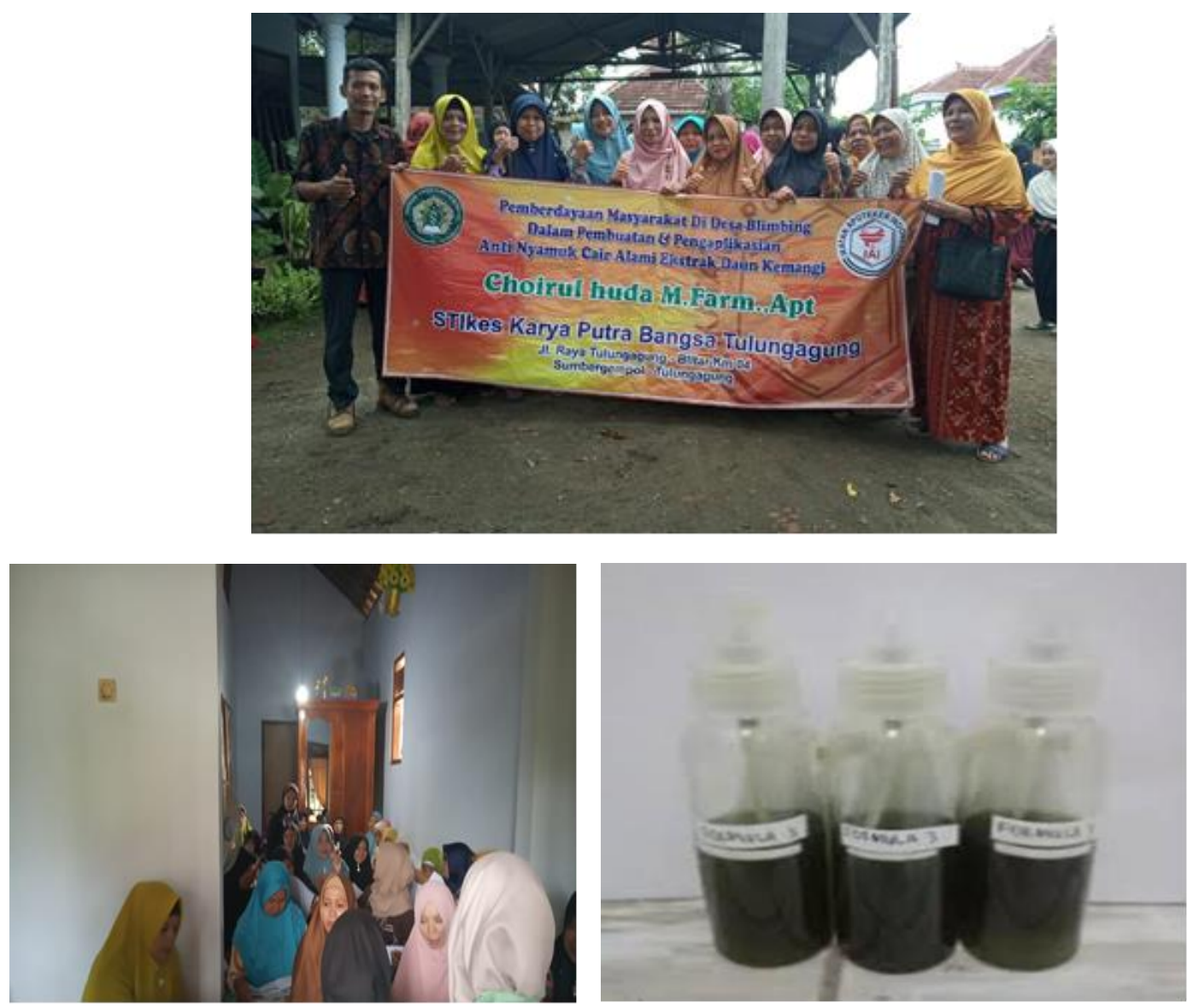


\section{KESIMPULAN}

Penyakit Demam Berdarah Dengue (DBD) atau Hemrrhagic Fever (DHF) ialah penyakit yang disebabkan virus dengue yang ditularkan melalui gigitan nyamuk Aedes aegyti dan Aedes albbopictus. Pelatihan singkat bertujuan untuk mencegahnya banyaknya masyarakat yang meninggal akibat penyakit demam berdarah dan peserta dapat memahami dan mengerti akan pentingnya pemberian antinyamuk berbahan dasar obat tradisional. Kegiatan pelatihan singkat merupakan bentuk kegiatan yang positif yang harus dikembangkan sehingga bemanfaat untuk masyarakat dan bisa menerapkan dalam kehidupan sehari-hari

\section{DAFTAR PUSTAKA}

Aryani R, Reni K, dan Siti R. (2012). Pengaruh Pemakaian Obat Anti Nyamuk Elektrik Berbahan Aktif D-Allethrin Terhadap Leukosit dan Trombosit Mencit (Mus musculus L). Mulawarman Scientifie. 11(1): 101-10.

Direktorat Jenderal, Pengendalian Penyakit dan Penyehatan Lingkungan. (2011). Pengendalian Demam Berdarah Dengue. Departemen Kesehatan Republik Indonesia, Jakarta.

Fauzia. (2007). Uji Aktifitas Antibakteri Daun Kemangi, Institut Pertanian Bogor.

Hartati, S.Y. (2012). Prospek Pengembangan Minyak Atsiri sebagai Pestisida Nabati. Perspektif Vol.11 No.1/Juni 2012. Balai Penelitian Tanaman Rempah dan Obat. Bogor.

Hoedojo, R. (2008). Morfologi, Daur Hidup, dan Perilaku Nyamuk: Parasitologi Kedokteran Edisi Ke-4. Fakultas Kedokteran. Universitas Indonesia. Jakarta.

Kementrian Kesehatan Republik Indonesia. (2018). Pusat data dan informasi demam berdarah tahun 2018.

Kementerian Kesehatan Republik Indonesia. (2013). Penyakit Menular NonNeglected: Kajian Program dan Penelitian. Badan Penelitian dan Pengembangan Kesehatan, Kementerian Kesehatan RI, Jakarta.

Kurniawan. (2011). Uji Efektivitas Larvasida Ekstrak Daun Binahong (Anredera Cordifolia (Ten.) Steenis) terhadap Larva Aedes Aegypti Instar III. Universitas Negeri Lampung, Lampung.

Maryorie, R. (2014). Uji Efek Teratogen Anti Nyamuk Bakar yang Mengandung Transfluthrin Terhadap Fetus Mencit Putih. Universitas Andalas, Padang.

Novizan. (2002). Membuat dan Memanfaatkan Pestisida Ramah Lingkungan. Jakarta: Agromedia Pustaka, hh: 37-40.

Fina, S. (2014). Uji Efektivitas Ekstrak Kulit Buah Duku (Lansium domesticum corr) sebagai antinyamuk elektrik terhadap daya bunuh nyamuk Ae. aegypti. Skripsi. Universitas Negeri Gorontalo 